\title{
大地は生きている
}

一一国人の地理思想—- -

宮崎市定

科学の発展は㳣して神秘を完全に征服してしまうあのではなく,ただそれを遠方へ 追いやるだけである。科学がまで進歩しないとき, 融秘は人間のそば近くに群がつ て、らようよしていた。その神秘のなかに何かの道理を見つけようとして理論を組立 てるのが，学問の萠芽である。古代人の物事に対する考え方は無邪気で幼椎である が，現今でもまだ神秘の世界が解消していない限り，我々も時には新たなる神秘に対 して，古代人のよろな童心の警きをるつ必要がないだろらか。

古代中国人が土地に対して抱いた観念は大体二通りに分れると思われる。第一は土 地は天と相対して表裏不可分の関係にたつているという考え方である。元来地理とい 了言葉は天交に対するもので，天に日月星辰のような文（模様）があると同様に，地 にも山野河海の理（きめ）があるという考元に基づく。光から地上の現象は密接に天 上と相応ずるもので，政治の仕方が悪いと日蝕が起り，天に彗星が現われると地上に 洪水や地震などの災害が起るとする。ところで天体はいつる迴つているから，どの部 分が地上の何処に当るかをきめておかねばならぬ。そこに分野という考えが起つてき た。この学説は戦国頃 (403B.C.〜221B.C.) に盛んになつたものなので，中国をだ いたい南から東，北，西にまわり，再び南へもどる円に従い，当時の有力国家であ る鄭, 宋, 燕, 越, 只, 隮, 衛, 骨, 魏, 趙, 秦, 凬, 楚の13部に分ち, それぞれの 土地が天球の黄道28宿上のどの部分に相応ずるかを定める。天球上の標準を黄道にと つたのは，云うまでもなく避星がこの附近を回転するからである。そこでたとえば黄 道上の毫牛星座のあたりに彗星が現れたならば，その分野たる越の地方に何か災害が 起る前ぶれだとして警戒しなければならぬ。分野については央記, 漠書, 淮南子など に詳しい記載があるが，この考えはずつと後世まで続いて，清代までの中国地志の目 頭には，必ず分野という項目が設けられて，その地方が何星座の分野に当つているか を示している。 
ところがだんだん経験をつむと，この分野の説は少しも当てにならないことが分つ てきた。その上秦漢以後，天下一統の世の中になると，天子一人が天下の政治に対し て責任をもつことになるので，地上の分野という考えも，分裂割拋の時代のような意 味をもたなくなつてしまつた。また一方には中国人の地理的智識が拡大されてくる と，分野のない土地が出てくる。もつともそれは苩の分野を払大してゆけばすむが， そうすると学の面積と㘩の面積とが比例しなくなり，かつまた中国以外の外国をどう するかという間題も出てきて，地上の現象は到底天上の現象をもつてしては説明でき ないことが分つてきた。

そこで代つて勢力を得たのが第二の考え方で，これは土地を天から一応切り離し て，土地は土地で説明しようとする。そして土地の神秘性を説明するために，大地は 生きていると仮定する。それが地気という言葉で表現されるが，気というのは人間の 呼吸を意味するうに生の表幑である。土地も人体のように，血が通つていて，そこ から気を発散し，それが万物を荃らのである。地下の鉱物なども，この気が養成した

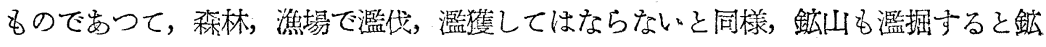
物が根絶してしまつて出なくなる。だから少しづつ採掘して，そのあとを埋めておく と，長い間に再び鉱物が生長すると考える。あまり急いで鉱石をとりすぎると，鉣脈

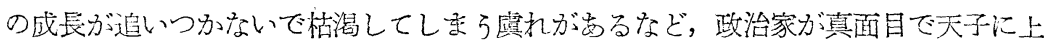

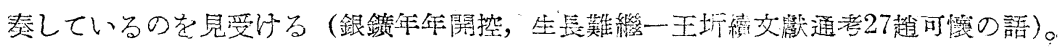

人閒は最も多く地気の作用を受ける。地気の置盛な場所に悬をつくるとその子供が 栄え，そこい家を立てれば家運が繁昌する。そこで地相の学(?)が成立するが，これ をも地理という。宋代以後この国法が一般化して, 地理正宗, 地理全書などいう名前 の本が岕るが，それは Geography ではなくて，墓相，家相のことばかり畫いて昰る。

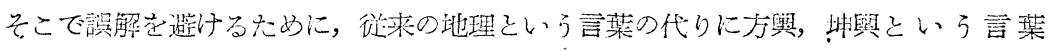

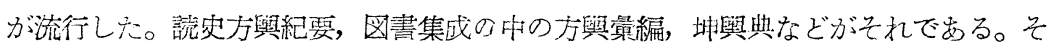
して地相家の説によると地気を包含した脈が地中を血管のように通つているのである がっこの脈に当るか当ら妨かは、ごく僅かの距離できなる微炒な問題で，専門の術士で も失敗することがあるというからむづかしい。微州の胡某というものが，賽婦を強迫 して亡夫の葬地と定つている土地を案き上げて，そご父を葬つたところが，そこは 役にた〉ない䒈穴の地であつて，間もなく子孫が絶隇し，これに反して宾娓が胡某か ら代りに与えられた土地に夫を葬つたところ，その地は霊穴であつて子孫が栄え，進 
土及第者を多数出したという話もある（梁萑慰勸我錄選 7 食詐）。もちろん，この家 相, 墓相の説は科学的根拋をもたないので, ぞうしても説明のつかぬ実例もでてく る。杭州の葛菒という者が，䱥縁仏の墓地を横領して，大君の墓地として朱氏に売り つけた。子孫の絶えた者の墓地として不吉なことが帮証されている䇺に拘らず，朱氏 の家が繁昌し，反つて詐偽を行つた葛某の子孫が絶えたという(酄我錄選 7 )。こう いろ事実は中国民族が艮い歴茰の間にいくらも経験したことがあろらが，これに対す る説明として，人工によつて自然の地脈も変動するという考がまた古くからある。す なわち自然に地脈が流れている場所でる，その上流を開掘すると霊気が洩れてしまつ て折争の地脈が枯渴してしまうというのである。秦の始皇帝に仕えた名将蒙佸が二世 皇帝の時，罪なくして死を賜ふつたが，死に臨んで自ら告白し，自分は万里の長城を 築くような大工事を起して，地脈を多く切断し，そのためどれほど他人の子孫を絶隇 させたか知れ妨ら，この報いは当然かもしれ好之語つている(定記88蒙恬傅)。

だから後世も帝王の陵墓の附近で工事を行うのは禁物で, 明代の天子の祖先の琹の ある鳳陽府では霊気を洩らさぬために，水利工事を笑施することができないで人民が ひどく团つをことがある（天下郡國利病韾34泗州志河防）。既に墓地の所在によつて 個人の子棌が衰えたり盛んになつたりするならば，国家の興亡といろことも必然的に 地気の盛衰で説明されなければならない。これは地脈にしても余程太い大きな動脤が 地下を通つているとせねね゙話が合はない。そこでこの太い動脈に龍腿という名をつけ る。顧炎武の天下郡国和病書の初的の所に引いた王土性という人の地脈の説にそれが 説明して岉る。これによると中国の地脈の起点はコンロン山脈であり，そこから三つ

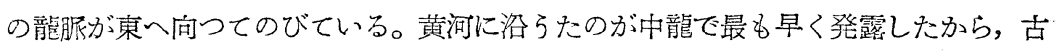
代の首都乞なつた艮安，洛陽，開封はみなこの線上にある。次に揚子江に沿つたのが 南龍で三国南北朝の都の趡康が堵われ，南宋時代の杭州の都となり，明代には太租が. 鳳隄から起り南京に都した。最も遅れて発したのが長城の線に沿ら北龍であり，遼金 の頃から盛んになり, 元代に北京が都と定まり, 明も永楽帝の時から北京に都を移す ことになつた，と云うのである。

清朝が満洲から起つて北京に入り中国全土の主人となつたことは，ますますこの説 を発達さしめた。有名な史家趙翼は，王気は東北に向つて移動するという議論を立て てこれを説明したことが，内藤湖南博士の近世文学史論の附録「地勢臆説」に引用さ れこれについての博士の批判がのつている。 
中国思想の面白いところは，分析を加えずにいきなり総合する点にある。これは中 国の美術や交学にも現はれる傾向で，また中国医学が病因の分析をせずに総体的に体 力と気力の恢復を計万弓とするに体つている。資源だとか，影観だとか，交通だとか を問題とせずに，頭から人交現象の变遷を地形で総合的に説明しょうとしたなら，い きおひころいう地気移動説に落ちつかざるを得ないであろう。そして大地が生きてい るとい弓命題は，ある点では現今も真理である。土地と人類との相関関保において， もし人類の活勘をも自然の中に含めて，たと艺ば勘植物の分布を自然景観として考兄 ると同じように取扱うならば，土地は生き物という外はない。土中で釯脈が生長する という考え方も，ばかばかしいと云つてしまえばそれ末でであるが，鉱石をとりつく してしまつていつたん廃岇となつた場所が，技術の発達によつて再び優秀な鉱山とし て再生する場合など，人類の方が鉱脈に近づいたとも見られるし，また鉣脈が再び人 類に近づいたとも見られる。それを鉱脈の生長といら言葉で現わしても大した不合理 はなさそろに思える。現今世界の政治，交化の中心は次第にアメリカやャシアの新開 地に移りつつあるが，これる地気移動論で説明できないであううか。 
Also, while Polynesians got to almost all islands in the Pacific by means of their primitive canoes, Phoenicians had possessed better vessels and navigation than Polynesians.

If indirect evidence such as above mentioned is taken into accounts, the circumnavigation of Africa by Phoenicians may be considered "gar nicht unwahrscheinlich," as remarked by Humboldt.

\section{THE EARTH IS LIVING}

\section{ICHISADA MIYAZAKI}

The Ancient Chinese usually had two kinds of ideas for the earth. The first idea, which diffused in the Age of Chan-Kuo, (戦国時代), was that phenomena in the heaven correspond with those on the earth i. e., a solor eclipse or an appearence of a comet suggested a misgovermment, a flood or an earthquake, and a each part of the globe of the heaven corresponds with a each part of several big countries in China.

According to second ides, which deffused after the first idea, phenomena of the earth, separating from those in the heaven, was used to be explained by the idea of "vigor of the earth". The earth has "vigor of the earth" in it, which wade all the animals, plants and minerals vigorous. And "vigor of the earth" liad many complex belts, people and things which was animated by the act of this vigor but those who were not on those belts were not influenced by this vigor. But the system of these belts was artificially changeable. And it was said that in China there was three main belts cf "vigor of the earth" ("Dragon Belt" (龍脈) etc.). By the idea of Dragon Belt they want to explain historically the rise and fall of Chinese countries, and the other two ideas had remained alive uutil Chin (清) dynasty.

\section{DIE WESTSLAWISCHE SIEDLUNGSWEISE IM OSTELBISCHE MITTELALTER}

